\title{
TINJAUAN SISTEM PENYIMPANAN DOKUMEN REKAM MEDIS DI RSU SINAR HUSNI TAHUN 2019
}

\author{
1. Ary Syahputra Wiguna; ${ }^{2 .}$ Desy Risma Safitri \\ 1. Dosen Prodi D-III Perekam Dan Infokes Imelda, Jalan Bilal Nomor 52 Medan; ${ }^{2}$ Alumni D-III Perekam \\ Dan Infokes Imelda
}

E-mail: ${ }^{1 .}$ aryesyah1@gmail.com

\begin{abstract}
ABSTRAK
Rekam medis ialah berkas yang berisikan catatan dan dokumen tentang identitas pasien, pemeriksaan, pengobatan, tindakan, dan pelayanan lain yang telah diberikan kepada pasien. Sistem Penyimpanan merupakan suatu kegiatan menyimpan rekam medis bertujuan untuk melindunginya dari kerusakan fisik dan isi dari dokumen tersebut. Sistem penyimpanan dokumen rekam medis merupakan salah satu faktor yang sangat dalam pemberian pelayanan di rumah sakit. Adapun sistem penyimpanan di RSU Sinar Husni tidak menggunakan tracer dan masih manual pada saat pengambilan rekam medis, masih ada berkas rekam medis yang disimpan di dalam kardus dikarenakan kurangnya rak penyimpanan sehingga memperlambat petugas dalam menyediakan rekam medis untuk pelayanan. Tujuan dari penelitian ini untuk mengetahui pelaksanaan sistem penyimpanan dokumen rekam medis. Jenis Penelitian ini adalah deskriptif. Populasi penelitian ini adalah seluruh petugas rekam medis di bagian penyimpanan berjumlah 2 orang. Sampel penelitian ini adalah seluruh populasi yang ada. Pengumpulan data penelitian ini dilakukan dengan pedoman wawancara dan observasi. Hasil dari penelitian ini adalah bahwa sistem penyimpanan rekam medis di RSU Sinar Husni menggunakan sistem sentralisasi, penjajarannya menggunakan terminal digit filling tetapi masih ada berkas rekam medis yang disimpan di dalam kardus dikarenakan kurangnya rak penyimpanan rekam medis dan pengambilan rekam medis menggunakan buku ekspedisi.
\end{abstract}

Kata Kunci: Petugas, Pelaksanaan, Penyimpanan.

\section{PENDAHULUAN}

Menurut UU RI Nomor 44 Tahun 2009 tentang Rumah Sakit, menyebutkan bahwa rumah sakit merupakan institusi pelayanan kesehatan yang menyelenggarakan pelayanan kesehatan perorangan secara paripurna yang menyediakan pelayanan rawat inap, rawat jalan dan gawat darurat. Rumah sakit merupakan institusi pelayanan kesehatan bagi masyarakat dengan karakteristik tersendiri yang dipengaruhi oleh perkembangan ilmu pengetahuan kesehatan,

Kemajuan teknologi dan kehidupan sosial ekonomi masyarakat yang harus tetap mampu meningkatkan pelayanan yang lebih bermutu dan terjangkau oleh masyarakat agar terwujud derajat kesehatan yang setinggi-tingginya.

Berdasarkan Peraturan Menteri Kesehatan RI Nomor 55 Tahun 2013 Bab I pasal 1 tentang penyelenggaraan pekerjaan perekam medis, menyebutkan bahwa rekam medis merupakan berkas yang berisi catatan dan dokumen tentang identitas pasien, pemeriksaan, pengobatan, tindakan dan pelayanan lain kepada pasien pada fasilitas pelayanan kesehatan. Manajemen Pelayanan Rekam Medis adalah kegiatan menjaga, memelihara dan melayani rekam medis baik secara manual maupun elektronik sampai menyajikan informasi kesehatan di rumah sakit, praktek dokter klinik, asuransi kesehatan, fasilitas pelayanan kesehatan dan lainnya yang menyelenggarakan pelayanan kesehatan dan menjaga rekaman. 
Berdasarkan Peraturan Menteri Kesehatan RI Nomor 269 Tahun 2008 Bab III pasal 7 tentang cara penyelenggaraan rekam medis, menyebutkan bahwa sarana pelayanan kesehatan wajib menyediakan fasilitas yang diperlukan dalam rangka penyelenggaraan rekam medis.

Menurut Peraturan Menteri Kesehatan RI Nomor 269 Tahun 2008 Bab IV pasal 8 tentang penyimpanan, pemusnahan dan kerahasiaan, menyebutkan bahwa rekam medis pasien rawat inap di rumah sakit wajib disimpan sekurang-kurangnya untuk jangka waktu 5 (lima) tahun terhitung dari tanggal terakhir pasien berobat atau dipulangkan. Setelah batas waktu 5 (lima) tahun rekam medis dapat dimusnahkan, kecuali ringkasan pulang dan persetujuan tindakan medik. Ringkasan pulang dan persetujuan tindakan medik harus disimpan untuk jangka waktu 10 (sepuluh) tahun terhitung dari tanggal dibuatnya ringkasan tersebut. Penyimpanan rekam medis dan ringkasan pulang dilaksanakan oleh petugas yang ditunjuk oleh pimpinan sarana pelayanan kesehatan.

Berdasarkan hasil penelitian Onick Mustika di RSUD dr. Moewardi Surakarta Tahun 2011 tentang pelaksanaan penyimpanan dan penjajaran dokumen rekam medis di ruang filling, ditemukan adanya kejadian salah letak (missfile), hal ini dikarenakan kurangnya ketelitian petugas dalam melakukan penyimpanan dan tidak digunakan tracer pada saat pengambilan dokumen rekam medis sehingga pada saat penyimpanan tidak ada alat bantu sebagai pedoman dalam penyimpanan dokumen rekam medis kembali serta terdapat sebagian dokumen rekam medis yang tidak menggunakan kode warna.

Berdasarkan hasil penelitian Djoko Kusnadi di RS Orthopedi Prof. Dr. R. Soeharso Surakarta Tahun 2018 tentang sistem penyimpanan dokumen rekam medis, telah diidentifikasi adanya permasalahan yaitu tempat penyimpanan yang tidak jadi satu atau terpisah-pisah, terjadinya missfile dan lamanya proses pencarian rekam medis, hal ini menyebabkan penyediaan dokumen rekam medis baik untuk pelayanan kepada pasien maupun keperluan lain akan menjadi lebih lama.

Berdasarkan hasil wawancara kepada petugas rekam medis pada bulan Februari di RSU Sinar Husni di rekam medis pada bagian penyimpanan rekam medis, penulis menemukan masalah dalam penyimpanan rekam medis yaitu tidak digunakan tracer pada saat pengambilan rekam medis, masih ada berkas rekam medis yang disimpan di dalam kardus dikarenakan kurangnya rak penyimpanan sehingga memperlambat petugas dalam menyediakan rekam medis untuk pelayanan, hal ini menyebabkan terganggunya pelayanan yang diberikan kepada pasien.

Adapun rumusan masalah yang terjadi dalam penelitian ini berdasarkan dari latar belakang yaitu Bagaimana pelaksanaan sistem penyimpanan berkas rekam medis yang ada di Rumah Sakit Umum Sinar Husni Tahun 2019?

\section{Tujuan Penelitian}

Adapun tujuan dalam penelitian ini untuk mengetahui pelaksanan sistem penyimpanan berkas rekam medis di Rumah Sakit Umum Sinar Husni Tahun 2019.

\section{Manfaat Penelitian}

1. Bagi Rumah Sakit

Penulis berharap hasil penelitian ini dapat menjadi masukan bagi Rumah Sakit sebagai bahan perbaikan dalam meningkatkan sistem penyimpanan berkas rekam medis di Rumah Sakit Umum Sinar Husni Medan.

2. Bagi Intitusi Pendidikan

Manfaat penulisan ini sebagai penambah wawasan serta dapat mengetahui bagaimana sistem penyimpanan berkas rekam medis di rumah sakit agar lebih berkembang sesuai dengan semakin luas pengetahuan tentang rekam medis. Dan untuk menambah referensi pustaka yang akan digunakan untuk penelitian selanjutnya, khususnya dibidang rekam medis. 


\section{METODE}

\section{Jenis Penelitian}

Jenis penelitian ini adalah penelitian deskriptif yaitu suatu metode penelitian yang dilakukan dengan tujuan utama untuk membuat gambaran atau deskripsi tentang suatu keadaan atau area populasi tertentu yang bersifat faktual secara objektif, sistematis dan akurat (Sulistyaningsih, 2011).

Penelitian dilakukan pada bulan Maret s/d Agustus 2019 sampai Juli 2018. Penelitan dilakukan di Rumah Sakit Umum Sinar Husni. Populasi adalah keseluruhan subjek penelitian. Subjek penelitian berupa benda. Semua benda yang memiliki sifat (atribut) atau ciri, adalah subjek yang bisa di teliti (Machfoedz, 2016). Populasi dalam penelitian ini adalah petugas rekam medis di bagian penyimpanan berjumlah 2 orang.

Sampel adalah sebagian dari populasi yang mewakili suatu populasi (Saryono, 2013). Sampel dalam penelitian ini adalah petugas rekam medis di bagian penyimpanan berjumlah 2 orang.

Instrumen penelitian adalah alatalat yang akan digunakan untuk pengumpulan data (Notoatmodjo, 2012). Instrumen penelitian yang digunakan dalam penelitian ini adalah pedoman wawancara dan observasi sebagai langkah awal penelitian terhadap pelaksanaan sistem penyimpanan rekam medis. Pengumpulan data dilakukan dengan wawancara dan observasi

\section{Analisis Data}

Data akan dianalisis dengan menggunakan metode deskriptif yaitu mengetahui gambaran pelaksanaan sistem penyimpanan rekam medis.

\section{HASIL}

Berdasarkan wawancara di atas yang dilakukan peneliti kepada petugas 1 dan petugas 2 mengenai sistem penyimpanan rekam medis di RSU Sinar Husni Tahun 2019, diperoleh hasil yang hamper sama jawabannya dari masingmasing petugas.

Berikut adalah hasil penelitian yang dilakukan peneliti yaitu :

1. Kebijakan tentang Penyimpanan Rekam Medis di RSU Sinar Husni

Berdasarkan wawancara oleh peneliti kepada 2 petugas di bagian penyimpanan rekam medis yang bertugas melakukan penyimpanan rekam medis pasien rawat jalan, rawat inap, dan gawat darurat sudah mempunyai kebijakan tentang penyimpanan rekam medis sesuai dengan jawaban petugas 1 dan petugas 2 yang memiliki jawaban yang sama.

2. Manfaat dari Kebijakan Penyimpanan Rekam Medis di RSU Sinar Husni

Berdasarkan wawancara kepada petugas 1 dan petugas 2 di bagian penyimpanan yang memiliki jawaban yang hampir sama menyatakan bahwa manfaat dari kebijakan penyimpanan rekam medis dapat mempermudah petugas dalam penyimpanan dan pengambilan kembali rekam medis karena sudah adanya pedoman dalam hal penyimpanan rekam medis.

\section{Pelaksanaan Penyimpanan Rekam Medis di RSU Sinar Husni \\ Berdasarkan wawancara kepada} petugas 1 dan 2 di bagian penyimpanan yang memiliki jawaban yang sama dalam pelaksanaan penyimpanan rekam medis pasien rawat jalan, rawat inap, dan gawat darurat sudah ada sejak mulai tahun 2008 yang telah disimpan di bagian penyimpanan rekam medis dengan sistem penyimpanan secara 
sentralisasi dan penjajaran rekam medis dengan dilakukan secara terminal digit filling. Pelaksanaan penyimpanan rekam medis dilakukan setelah pasien selesai memperoleh pelayanan, berkas yang telah kembali dari unit pelayanan kemudian dilakukan foldering (map) dan assembling serta evaluasi kelengkapan pengisian rekam medis. Untuk berkas rekam medis yang sudah lengkap dapat dilakukan penyimpanan ke dalam rak penyimpanan, sedangkan untuk berkas rekam medis yang belum lengkap dikembalikan ke unit pelayanan untuk dilengkapi. Pada saat petugas melakukan penyimpanan ke dalam rak penyimpanan rekam medis yang telah diberi map terlebih dahulu dikelompokkan menurut angka akhir. Setelah dilakukan pengelompokkan, berkas rekam medis dimasukkan ke dalam rak penyimpanan sesuai nomor rekam medisnya.

Selain itu, petugas penyimpanan rekam medis juga melakukan pengambilan kembali (retrieval) berkas rekam medis pasien rawat jalan, rawat inap dan gawat darurat. Sebelum menuju ke rak penyimpanan petugas penyimpanan melihat terlebih dahulu 2 angka akhir nomor rekam medis pasien. Selanjutnya petugas penyimpanan mengambil rekam medis pasien sesuai nomor rekam medis dan memastikan isi dokumen tersebut sudah sesuai.

\section{Buku dan Catatan yang Digunakan} dalam Pengambilan Rekam Medis di RSU Sinar Husni

Berdasarkan wawancara kepada petugas 1 dan petugas 2 di bagian penyimpanan yang memiliki jawban yang sama dalam pengambilan atau penyerahan rekam medis di RSU Sinar Husni menggunakan buku ekspedisi yang digunakan untuk mencatat rekam medis yang dipinjam setiap hari. Buku ekspedisi di RSU Sinar Husni berisi tanggal pinjaman, nomor rekam medis, nama pasien, nama atau ruangan yang meminjam, paraf berkas dipinjam, paraf berkas kembali dan keperluan peminjaman. Akan tetapi dalam pengambilan rekam medis di RSU Sinar Husni tidak menggunakan tracer sebagai petunjuk rekam medis keluar.

5. Hambatan dalam Pelaksanaan Penyimpanan Rekam Medis di RSU Sinar Husni

Berdasarkan wawancara kepada petugas 1 dan petugas 2 di bagian penyimpanan yang memiliki jawaban yang sama bahwa hambatan dalam pelaksanaan penyimpanan rekam medis di RSU Sinar Husni yaitu masih ada berkas yang disimpan di dalam kardus karena kurangan rak penyimpanan.

Adapun penyimpanan keterlambatan berkas rekam medis yang selalu menjadi hambatan yaitu :

\section{Apotek}

Lamanya petugas apotek dalam pencatatan nama obat yang di gunakan oleh pasien dan tidak jelasnya penulisan dokter nama obat tersebut menyebabkan petugas apotek harus berkoordinasi dengan dokter.

2. Administrasi

Mencatat status pasien tersebut dan menghitung total pembayaran biaya rumah sakit.

\section{PEMBAHASAN}

1. Kebijakan tentang penyimpanan Rekam Medis di RSU Sinar Husni

Di RSU Sinar Husni telah memiliki kebijakan tentang penyimpanan rekam medis yang diatur secara lengkap. Sehingga petugas dalm melaksanakan penyimpanan rekam medis memiliki pedoman yang sesuai dengan kebijakan yang telah ditetapkan yaitu penyimpanan rekam medis menggunakan sistem sentralisasi dan penjajarannya secata terminal digit filling. Dari segi 
pelaksanaannya petugas sudah melakukan penyimpanan rekam medis seuai dengan kebijakan yang telah dibuat.

2. Manfaat dari Kebijakan Penyimpanan Rekam Medis di RSU Sinar Husni Manfaat dari kebijakan penyimpanan rekam medis di RSU Sinar Husni yaitu dapat mempermudah petugas dalam penyimpanan dan pengambilan kembali rekam medis karena sudah memiliki pedoman. Hal tersebut sudah sesuai dengan (Permenkes No. 512, 2007) dimana standar prosedur operasional memberikan langkah yang benar dan terbaik berdasarkan konsensus bersama untuk melaksanakan berbagai kegiatan dan fungsi pelayanan yang dibuat oleh sarana pelayanan kesehatan berdasarkan standar profesi.

\section{Pelaksanaan Penyimpanan Rekam Medis di RSU Sinar Husni \\ Dalam pelaksanaan penyimpanan} rekam medis baik rawat jalan, rawat inap dan gawat darurat sudah sesuai dengan kebijakan yaitu secara sentralisasi dan penjajarannya secara terminal digit filling. Hal ini sudah sesuai menurut Depkes RI yang menyatakan bahwa berkas rekam medis sebaiknya menggunakan sentralisasi karena secara teori cara sentralisasi lebih baik dari pada desentralisasi sehingga berkas rekam medis tersimpan dalam satu kesatuan.

4. Buku dan Catatan yang Digunakan dalam Pengambilan Rekam Medis di RSU Sinar Husni

Dalam pelaksanaan pengambilan rekam medis pasien rawat jalan, rawat inap dan gawat darurat membutuhkan buku dan catatan. Buku peminjaman digunakan untuk mengetahui tujuan peminjaman rekam medis, agar petugas penyimpanan mudah dalam mencari jika suatu saat rekam medis tersebut dibutuhkan untuk pelayanan dan untuk serah terima rekam medis petugas penyimpanan menggunakan buku ekspedisi. Pengambilan rekam medis di RSU Sinar Husni sudag sesuai dengan (Depkes RI, 2006) bahwa dalam serah terima rekam medis dengan menggunakan buku ekspedisi yang bertujuan agar keamanan rekam medis terjamin untuk menghindari kehilangan rekam medis dan sebagai bukti serah terima antar peminjaman dan petugas penyimpanan rekam medis.

Sedangkan pengambilan rekam medis di RSU Sinar Husni tidak menggunakan tracer sebagai petunjuk rekam medis keluar.Hal ini belum sesuai dengan (Depkes RI, 2006) bahwa tracer berguna untuk mengawasi penggunaan rekam medis sebagai rekam medis yang dipinjam dan pengambilan rekam medis harus menggunakan tracer atau kartu peminjaman rekam medis.

5. Hambatan dalam Pelaksanaan Penyimpanan Rekam Medis di RSU Sinar Husni

Hambatan pelaksanaan penyimpanan rekam medis masih ada berkas yang disimpan di dalam kardus karena kurangnya rak penyimpanan sehingga memperlambat petugas dalam penyimpanan dan pengambilan rekam medis.

Hal tersebut belum sesuai dengan buku (Indradi, 2017) bahwa semua berkas rekam medis harus disimpan di rak penyimpanan sehingga akan mempermudah petugas dalam penyimpanan rekam medis.

\section{KESIMPULAN}

Berdasarkan hasil dan pembahasan penelitian yang telah dilakukan yang berjudul "Tinjauan Sistem Penyimpanan 
Dokumen Rekam Medis di RSU Sinar Husni Tahun 2019", maka diperoleh kesimpulan sebagai berikut :

1. Sistem penyimpanan rekam medis di RSU Sinar Husni menggunakan sistem sentralisasi.

2. Sistem penjajaran di RSU Sinar Husni menggunakan dua angka akhir (terminal digit filling) dan masih ada berkas rekam medis yang disimpan di dalam kardus dikarenakan kurangnya rak penyimpanan rekam medis.

3. Sistem peminjaman rekam medis sudah menggunakan buku ekspedisi yang digunakan untuk mencatat rekam medis yang dipinjam setiap hari, sedangkan penggunaan tracer untuk pengambilan rekam medis dari rak penyimpanan belum dilakukan.

\section{SARAN}

Berdasarkan kesimpulan di atas, disarankan kepada pihak rumah sakit yaitu:

1. Sebaiknya pihak rumah sakit menambah sarana dan prasarana seperti rak penyimpanan rekam medis sehingga semua berkas rekam medis dapat tersusun dengan rapi di rak penyimpanan rekam medis (tidak disimpan di kardus).

2. Sebaiknya digunakan tracer agar lebih bisa mengawasi penggunaan rekam medis yang diletakkan sebagai pengganti berkas rekam medis yang diambil (dikeluarkan) dari rak penyimpanan.

\section{DAFTAR PUSTAKA}

Azwar, Azrul. (1996). Menjaga Mutu Pelayanan Kesehatan. Jakarta: pustaka sinar harapan.

DepKes RI. (2006). Pedoman Penyelenggaraan dan Prosedur Rekam Medis Rumah Sakit di Indonesia. Jakarta: DepKes RI.
Dirjen, Yanmed. (2006). Pedoman Penyelenggaraan dan Prosedur Rekam Medis Rumah Sakit di Indonesia Revisi II. Jakarta.

Hatta, Gemala R. (2009). Pedoman Manajemen Informasi Kesehatan Di Sarana Pelayanan Kesehatan. Jakarta: UI-Press.

Indradi, S, Rano. (2017). Rekam Medis. Tangerang Selatan: Universitas Terbuka.

Kementerian Kesehatan RI. (2008). Peraturan Menteri Kesehatan Republik Indonesia Nomor 269 Tentang Rekam Medis. Jakarta: Dapertemen Kesehatan.

Kusnadi, D. (2018). Sistem penyimpanan Dokumen Rekam Medis di RS Orthopedi Prof. Dr.R. Soeharso. Surakarta.

Mathar, Irmawati. (2018). Manajemen Informasi Kesehatan: Pengelolaan Dokumen Rekam Medis. Yogyakarta: Deepublish.

Mawarni, D. \& Wulandari, R. D. (2013). "Identifikasi Ketidaklengkapan Rekam Medis Pasien Rawat Inap Rumah Sakit Muhammadiyah Lamongan".

Mustika, O. (2011). Pelaksanaan Penyimpanan dan Penjajaran Dokumen Rekam Medis di Ruang Filling RSUD dr. Moewardi. Surakarta.

Notoatmodjo, S. (2012). Metodologi Penelitian Kesehatan. Jakarta: Rineka Cipta.

Peraturan Menteri Kesehatan RI Nomor 55 Tahun 2013. Penyelenggaraan Pekerjaan Perekam Medis. Jakarta: Depkes RI.

Riyanto, B. (2012). Pelaksanaan Penyimpanan dan Pengambilan Dokumen Rekam Medis di Bagian Filling RSUD Kabupaten Karanganyar. Jawa Tengah.

Rustiyanto, Ery. (2009). Etika Profesi: Perekam Medis Informasi 
Kesehataan. Yogyakarta: Graha Sulistyaningsih. (2011). Metodologi Ilmu.

Saryono, dan Anggraeni M. (2013). Metodologi Penelitian Kualitatif dan Kuantitatif Dalam Bidang Kesehatan. Yogyakarta: Nuha Medika. Penelitian Kebidanan: KuantitatifKualitatif. Yogyakarta: Graha Ilmu. Undang-Undang Republik Indonesia Nomor 44 Tahun 2009. Rumah Sakit. Jakarta: Depkes RI. 